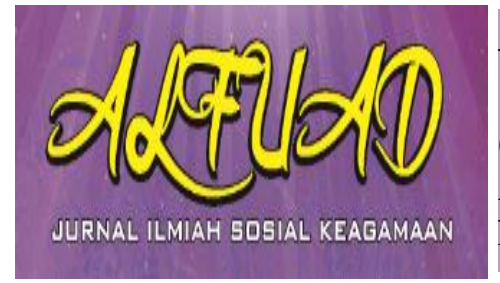

ALFUAD JOURNAL, 4 (1), 2020, (80-87)

(E-ISSN 2714-7606 P-ISSN 2614-4786 )

Available online at

http://ecampus.iainbatusangkar.ac.id/ojs/index.php/alfuad

\title{
PENGELOLAAN ARSIP DINAMIS PADA FAKULTAS USHULUDDIN ADAB DAN DAKWAH (FUAD) IAIN BATUSANGKAR
}

\section{Rika Jufriazia Manita}

Institut Agama Islam Negeri Batusangkar, Indonesia

E-mail:

rikajufriaziamanita@iainbatusangkar.ac.id

\begin{abstract}
Themanagement of dynamic records becomes the reference of an organization to achieve the goals of the organization. Dynamic archives will not be separated from correspondence in each unit at the agency. The background of this research is that the archives of Ushuluddin Adab and Da'wah (FUAD) IAIN Batusangkar have not been maximized. The research that the author uses is descriptive research with a qualitative approach. There were 4 informants in this assessment consisting of 1 Head of Administration and 4 archiving officers in the Faculty environment, are a receptionist manager, 3 departmental employees namely 1 Department of Library and Islamic Science Department 1 employee, Islamic Broadcast Communication 1 people and employees majoring in Islamic Political Thought 1 person. Based on observations made by the author, it can be concluded that the management of dynamic archives at the Faculty of Usuluddin Adab and Da'wah (FUAD) of Batusangkar IAIN has not run optimally, for the management of incoming and outgoing letters such as official letters, student letters in their distribution require a long time especially when the receptionist was not in place because the receptionist was a lecturer employed. Staff limitations and the difficulty in re-finding archives are due to the management of archives that are not in accordance with the standards and inadequate supporting facilities. Archival shrinkage in the Faculty of Usuluddin Adab and Da'wah has not used the Archive Retention Schedule
\end{abstract}

Keywords: Dynamic archive, Faculty of Usuluddin Adab and Da'wah

\section{PENDAHULUAN}

Setiap instansi, baik itu instansi pemerintahan maupun instansi swasta pasti memiliki bagian administrasi. Bagian administrasi merupakan bahagian yang sangat penting disetiap instansi karena bagian administrasi ini mempunyai tanggung jawab dan tugas yang cukup kompleks dalam tata kelola administrasi yang ada di instansi.Untuk menunjang kegiatan perkantoran agar berjalan dengan baik maka sebuah instansi membutuhkan dokumen, selain itu instansi juga melakukan perekapan data yang kemudian disimpan secara terstruktur sehingga memudahkan dalam penemuan kembali dokumen tersebut. 
Arsip adalah salah satu dokumen dan sumber data yang menjadi kebutuhan pokok bagi sebuah organisasi. Keberadaan arsip pada sebuah organisasi sangat diperlukan dalam rangka melaksanakan kegiatan-kegiatan perkantoran. Untuk itu, harus ada prosedur dan sistem kerja yang baik pada bidang kearsipan. Suatu organisasi tidak akan mampu memberikan data dan informasi secara lengkap apabila organisasi yang bersangkutan tidak memiliki pemeliharaan kearsipannya sesuai dengan peraturan dan ketentuan yang sudah diterapkan oleh pemerintah. Dapat disimpulkan bahwa peranan arsip memiliki nilai yang tinggi dalam pemberian, penyebaran, pelestarian dan perluasan informasi bagi yang membutuhkannya. Jenis arsip sebagaimana yang di kemukakan oleh Barthos, Basir (2012) ada 2 macam yaitu arsip dinamis dan arsip statis.

Arsip Dinamis adalah arsip yang masih diperlukan secara langsung dalam perencanaan,pelaksanaan,penyelenggaraan kehidupan kebangsaan pada umumnya atau arsip yang digunakan secara langsung dalam penyelenggaraan administrasi Negara.

Arsip Statis adalah arsip yang tidak dipergunakan secara langsung untuk perencanaan,pelaksanaan,penyelenggaraan kehidupan kebangsaan pada umumnya, maupun untuk penyelenggaraan administrasi sehari-hari.

Dalam hal ini penulis memfokuskan penelitian ini kepada pengelolaan arsip dinamis yang ada pada Fakultas Ushuluddin Adab dan Dakwah. Barthos, Basir (2012) juga menjelaskan bahwa arsip dinamis terbagi atas 2 bagian yaitu: (1) arsip aktif adalah arsip yang secara langsung dan terus menerus diperlukan dan digunakan dalam penyelenggaraan administrasi sehari-hari serta masih dikelola oleh unit pengolah. (2) arsip inaktif adalah arsip yang tidak secara langsung dan tidak terus menerus diperlukan dan digunakan dalam pengelenggaraan administrasi sehari-hari serta dikelola oleh pusat arsip.

Pengelolaan arsip dinamis menurut Peraturan Pemerintah Republik Indonesia No. 28 Tahun 2012, Bab 1, pasal 1, ayat 20 tentang pelaksanaan kegiatan kearsipan bahwa pengelolaan arsip dinamis meliputi: penciptaan, penggunaan, pemeliharan dan penyusunan arsip. Begitu juga dengan Fakultas Ushuluddin Adab dan Dakwah akan selalu memiliki dokumen atau arsip dinamis. Seluruh kegiatan yang dilakukan di Fakultas Ushuluddin Adab dan Dakwah tidak akan luput dari pengelolaan arsip dinamis dalam melaksanakan Tri Dharma Perguruan Tinggi yaitu pendidikan, penelitian dan pengabdian kepada masyarakat yang akan menghasilkan 
sebuah dokumen atau data sebagai informasi yang terekam. Apabila informasi terekam tidak disimpan dan diolah atau keberadaannya tidak di pertahankan maka informasi tersebut tidak akan berarti lagi bagi kehidupan. Tujuan pengelolaan arsip dinamis adalah untuk memelihara ketersediaan arsip sebagai alat bukti yang sah di dalam melaksanakan tugas pokok dan fungsi perguruan tinggi.

Fakultas Ushuluddin Adab dan Dakwah adalah fakultas termuda yang berada di IAIN Batusangkar. Pada Fakultas Ushuluddin Adab dan Dakwah ini terdapat 6 jurusan yaitu jurusan Ilmu Alquran dan Tafsir, Komunikasi Penyiaran Islam, Psikologi Islam, Ilmu Perpustakaan dan Informasi Islam, Pemberdayaan Masyarakat Islam dan Pemikiran Politik Islam. Bagian Administrasi diFakultas Ushuluddin Adab dan Dakwah dimulai dari Dekan, Wakil Dekan I, II dan III, Kabag Tata Usaha, Kasubag Administrasi Umum dan Keuangan, Kasubag Akademik Kemahasiswaan dan Alumni, dan Jurusan. Semua bagian yang ada di Fakultas Ushuluddin Adab dan Dakwah melakukan kegiatan kearsipan.

Pengelolaan arsip dinamis pada Fakultas Ushuluddin Adab dan Dakwah dikelola oleh unit-unit bagian, dimana arsip Fakultas dikelola oleh bagian Administrasi Umum dan keuangan, sedangkan arsip kemahasiswaan dikelola oleh bagian akademik kemahasiswaan dan alumni serta pengelolaan di jurusan. Tiaptiap jurusan yang ada di Fakultas Ushuluddin Adab dan Dakwah memiliki staf jurusan yang bertugas mengelola arsip kegiatan mahasiswa. Dalam penemuan kembali arsip-arsip pada Fakultas Ushuluddin Adab dan Dakwah memerlukan waktu yang cukup lama antara 5-10 menit bahkan lebih sehingga ruang penyimpanan arsip kurang kondusif karna arsip hanya disimpan pada folderfolder dan boks arsip. Sebagian unit dalam penyimpanan arsipnya sudah memiliki lemari arsip akan tetapi ada beberapa unit pada Fakultas Ushuluddin Adab dan Dakwah yang belum memiliki lemari arsip dalam penyimpanan arsipnya. Kendala lain dalam penyimpanan arsip adalah ruangan penyimpanan arsip kecil dan sempit. Banyak arsip yang disimpan dalam boks melebihi kapasitasnya mengakibatkan arsip menjadi kusut dan tumpang tindih. Kurangnya fasilitas yang dimiliki Fakultas Ushuluddin Adab dan Dakwah dalam penyimpanan arsip membuat arsip menjadi menumpuk bahkan banyak arsip disimpan dibawah meja kerja petugas dan tidak tertata dengan rapi.

Kendala lain yang ditemukan pada Fakultas Ushuluddin Adab dan Dakwah adalah belum dilaksanakannya penyusutan arsip secara periodik. Menurut Basir Barthos (2012) penyusutan arsip adalah 
proses kegiatan penyiangan arsip/ berkas untuk memisahkan arsip aktif dari arsipinaktif serta menyingkirkan arsiparsip yang tidak berguna berdasarkan jadwal retensi arsip. Tidak adanya jadwal penyusutan arsip secara periodik membuat arsip yang ada pada Fakultas Ushuluddin Adab dan Dakwah menjadi bertumpuk dan sulit dalam penemuan kembali arsip yang dibutuhkan.

\section{METODE}

Adapun metode penelitian kajian pustaka atau studi kepustakaan yaitu berisi teori teori yang relevan dengan masalah masalah penelitian. Pada bagian ini dilakukan pengkajian mengenai konsep dan teori yang digunakan berdasarkan literatur yang tersedia, terutama dari artikel-artikel yang dipublikasikan dalam berbagai jurnal ilmiah. Kajian pustaka berfungsi untuk membangun konsep atau teori yang menjadi dasar studi dalam penelitian. Kajian pustaka atau studi pustaka merupakan kegiatan yang diwajibkan dalam penelitian, khususnya penelitian akademik yang tujuan utamanya adalah mengembangkan aspek teoritis maupun aspek manfaat praktis. Sehingga dengan menggunakan metode penelitian ini penulis dapat dengan mudah menyelesaikan masalah yang hendak diteliti.

\section{HASIL DAN PEMBAHASAN}

Pengelolaan Arsip Dinamis Pada

Fakultas Ushuluddin Adab dan Dakwah Pengelolan arsip pada Fakultas Ushuluddin Adab dan Dakwah yang merupakan arsip dinamis salah satunya adalah surat masuk dan surat keluar. Bagian penerimaan surat masuk pada Fakultas Ushuluddin Adab dan Dakwah dikelola oleh Kasubag Administrasi Umum dan Keuangan dimana salah satu unit dibawahnya yang khusus mengelola surat masuk dan surat keluar adalah bagian resepsionis. Surat masuk yang diterima resepsionis dibaca dahulu oleh petugas resepsionis sebelum dicatat pada buku agenda untuk mengetahui tujuan dari surat tersebut. Setelah diketahui tujuan surat maka surat tersebut di catat pada buku agenda surat masuk. Surat yang ditujukan pada Dekan dilampirkan lembar disposisi kemudian surat tersebut diteruskan pada unit Kabag Tata Usaha sebelum diteruskan pada Dekan untuk diperiksa dan dibubuhi paraf. Selanjutnya surat diteruskan pada Dekan untuk diperiksa dan dibaca. Langkah selanjutnya, petugas resepsionis akan mencatat isi surat pada papan tulis kecil yang berada di ruangan Dekan. Tahapan akhirnya adalah mengarsipkan surat di unit resepsionis.

Apabila surat ditujukan pada unit lain yang ada dilingkungan Fakultas Ushuluddin Adab dan Dakwah maka 
setelah surat di periksa dan di catat pada buku agenda surat masuk di bagian resepsionis surat diteruskan pada Kabag Tata Usaha dan dibubuhi paraf kemudian surat diteruskan pada Dekan untuk diperiksa dan dibaca. Selanjutnya Dekan memberikan catatan pada lembar disposisi untuk ditindak lanjuti pada bagian unit yang dituju oleh surat. Langkah selanjutnya surat diteruskan pada unit yang di tuju dan kemudian diarsipkan oleh bagian resepsionis.

Pengelolaan surat keluar pada Fakultas Ushuluddin Adab dan Dakwah pertama kali adalah pembuatan konsep surat. Konsep surat tersebut diteruskan pada Kabag Tata Usaha untuk diperiksa. Hasil revisi Kabag Tata Usaha kemudian di ketik dan di print oleh pegawai. Apabila surat dialamatkan ke luar organisasi maka surat di paraf oleh Kabag Tata Usaha kemudian surat ditandatangani oleh pejabat yang berwenang. Setelah itu surat diberi nomor dan dicatat pada buku agenda surat keluar. Terakhir surat diberi stempel fakultas dan diarsipkan di bagian resepsionis. Surat siap didistribusikan ke instansi yang dituju. Namun ketika surat dialamatkan pada sivitas akademika Fakultas Ushuluddin Adab dan Dakwah misalnya surat untuk menghadiri rapat oleh sivitas akademika Fakultas Ushuluddin Adab dan Dakwah pendistribusian surat langsung diteruskan oleh resepsionis pada unit-unit yang dituju. Untuk mengingatkan kembali maka resepsionis akan menshare pada whatshapp grub.

\section{Penggunaan Asip pada Fakultas Ushuluddin Adab dan Dakwah} Peminjaman arsip adalah bagian dari penggunaan arsip yang berkaitan dengan penemuan kembali arsip tersebut. Arsip pada Fakultas Ushuluddin Adab dan Dakwah biasanya dipinjam oleh petugas/pegawai, pimpinan Fakultas atau dipinjam oleh pihak luar Fakultas. Proses peminjaman arsip oleh pihak Fakultas yaitu dengan cara mencatat pada buku peminjaman arsip. Apabila arsip dipinjam oleh pihak luar Fakultas arsip akan dicatat pada buku peminjaman dengan mengisi biodata lengkap dari si peminjam kemudian arsip tersebut di fotokopi kemudian arsip tersebut di kembalikan pada Fakultas. Arsip yang bisa dipinjamkan adalah arsip biasa, sedangkan arsip penting hanya bisa dipinjam oleh pimpinan Fakultas.

Penemuan kembali arsip pada Fakultas Ushuludiddin Adab dan Dakwah dengan menanyakan terlebih dahulu arsip yang dibutuhkan oleh pegawai kepada peminjam arsip. Setelah itu baru dilakukan pencarian arsip oleh pegawai di file- file, folder, lemari arsip atau tempat penyimpanan arsip. Ketika arsip tidak ditemukan maka pegawai akan 
membutuhkan waktu yang cukup lama dalam penemuan kembali arsip tersebut sebab sistem penyimpanan arsip pada Fakultas Ushuluddin Adab dan Dakwah menggunakan sistem penyimpanan secara manual.

Dari paparan diatas dapat disimpulkan bahwa penemuan kembali arsip di Fakultas Ushuluddin Adab dan Dakwah belom mengikuti peraturan tata kelola arsip yang sudah ditetapkan oleh pemerintah. Dalam penemuan kembali arsip tersebut belum mempergunakan kartu kendali dan tidak adanya pengklasifikasian sehingga pegawai kesulitan dalam penemuan kembali arsip tersebut.

\section{Pemeliharaan Arsip pada Fakultas Ushuluddin Adab dan Dakwah}

Arsip merupakan sumber informasi dari masa lalu dimana keberadaannya sangat dibutuhkan didalam sebuah organisasi demi kelangsungan organisasi. Untuk itu, pemeliharaan arsip sangat diperlukan supaya arsip menjadi terawat dengan baik dan terhindar dari kerusakan ataupun kehilangan arsip. Pemeliharaan arsip bertujuan untuk melindungi dan mencegah arsip dari kemusnahan yang tidak diinginkan.Kerusakan arsip dapat disebabkan oleh dua faktor yaitu faktor internal dan eksternal arsip itu sendiri. Dilihat dari faktor dalam yaitu kerusakan yang berasal dari arsip itu sendiri, seperti dari kertas arsip itu sendiri ataupun dari tinta maupun dari lem perekat kertasnya. Sedangkan kerusakan akibat serangan dari luar yaitu kerusakan yang diakibatkan oleh faktor kelembapan udara, sinar matahari, udara ataupun kerusakan yang disebabkan oleh jamur ataupun hewan-hewan kecil seperti rayap dan ngengat.

\section{Penyusutan Arsip pada Fakultas Ushuluddin Adab dan Dakwah}

Tahap akhir dalam melakukan manajemen kearsipan adalah kegiatan penyusutan arsip. Penyusutan arsip memiliki peranan yang sangat penting karena jumlah arsip yang tercipta pada suatu instansi akan selalu mengalami penambahan dan peningkatan sejalan dengan kegiatan-kegiatan yang dilakukan pada instansi dalam rangka meningkatkan tupoksi organisasi. Penambahan jumlah arsip akan mendatangkan kendala apabila tidak diberlakukan pengurangan pada arsip tersebut, diantaranya adalah dari segi biaya, ruangan tempat penyimpanan, pemeliharaan dan perawatan arsip. Selain itu arsip yang dibutuhkan dan arsip yang tidak dibutuhkan akan tercampur menjadi satu sehingga akan menyulitkan dalam penemuan kembali arsip tersebut.

Berdasarkan pasal pasal 2, PP No 34 Tahun 1979 di dalam Mirmani, Anon (2011) tentang penyusutan arsip ada 3 cara yang dapat dilakukan yaitu: Memindahkan arsip inaktif dari unit kerja 
ke unitkearsipan atau dari berkas aktif ke berkas inaktif (2) Memusnahkan arsip yang tidak bernilai guna berdasarkan peraturan yang berlaku (3) Menyerahkan arsip statis ke Arsip Nasional Republik Indonesia.

Kegiatan penyusutan arsip pada Fakultas Ushuluddin Adab dan Dakwah belum dilakukan sesuai dengan peraturan yang berlaku. Dalam melakukan penyusutan arsip di Fakultas Ushuluddin Adab dan Dakwah dengan cara memindahkan arsip inaktif ke ruangan penyimpanan arsip dan tidak memiliki jangka waktu secara berkala dalam penyusutan arsipnya. Penyusutan arsip dilakukan tidak terjadwal karena di Fakultas Ushuluddin Adab dan Dakwah tidak memiliki jadwal retensi arsip. Penyusutan arsip dilakukan secara prediksi saja, ketika arsip yang ada sudah jarang dipergunakan maka akan dilakukan penyusutan arsip.

\section{Hambatan-Hambatan Yang Dihadapi Pada Pelaksanaan Pengelolaan Arsip Dinamis Pada Fakultas Ushuluddin Adab dan Dakwah}

Adapun Hambatan yang dihadapi dalam pelaksanaan pengelolaan arsip dinamis pada Fakultas Ushuluddin Adab dan Dakwah adalah kurangnya sarana prasarana yang ada. Hal ini terjadi karena dalam melakukan pengadaan sarana prasarana memiliki prosedur yang panjang.
Pihak Fakultas harus melakukan pengajuan penambahan sarana prasarana terlebih dahulu kepada Institut. Dari institut akan dilakukan seleksi sebab terdapat fakultas lain yang juga membutuhkan sarana prasarana yang sama dengan cara melakukan pembagian sarana prasarana untuk tiap-tiap fakultas. Kemudian pihak fakultas juga melakukan pembagian terhadap unit-unit yang ada di lingkungannya.

Sumber Daya Manusia (SDM), Dalam melaksanakan pengelolaan arsip seharusnya dilakukan oleh pegawai kearsipan. Namun pelaksanaan yang terlihat di lapangan pada Fakultas Ushuluddin Adab dan Dakwah belum memiliki staf khusus bidang kearsipan. Tugas arsiparis dilakukan oleh Dosen yang dikaryakan sehingga dalam pelaksanaan tugas kearsipan tidak maksimal. Selain itu, arsip tidak tertata dengan rapi. Tidak adanya pelatihan atau workshop kepada pegawai dalam melakukan pengelolaan arsip sehingga pegawai tidak mengetahui tata cara pengelolaan arsip yang benar.

Dilihat dari segi ruangan Fakultas Ushuluddin Adab dan Dakwah dapat dilihat dalam penyimpanan arsipnya tidak kondusif dengan tidak terjaganya kebersihan tempat penyimpanan arsip. Selain itu tidak adanya kegiatan dalam pemeliharaan arsip yang dilakukan secara 
berkala yang mengakibatkan arsip menjadi bertumpuk di ruangan penyimpanan arsip.

\section{KESIMPULAN}

Berdasarkan penelitian dan pembahasan dapat disimpulkan bahwa tidak adanya Staf khusus yang mengelola kearsipan pada Fakultas Ushuluddin Adab dan Dakwah. Kurangnya pengelolaan arsip secara terstruktur oleh pegawai dikarenakan tidak adanya pelatihan atau workshop terhadap pegawai di bidang pengelolaan arsip pada Fakultas Ushuluddin Adab dan Dakwah. Kurangnya ruang penyimpana arsip pada Fakultas Ushuluddin Adab dan Dakwah mengakibatkan staf kesulitan dalam penemuan kembali arsip serta membutuhkan waktu yang cukup lama. Ketidak lengkapan sarana prasarana yang disediakan oleh kampus sehingga tidak tercapainya pengelolaan yang maksimal oleh pegawai.

\section{DAFTAR PUSTAKA}

Amsyah, Z. (2001). Manajemen Kearsipan. Cet 9. Jakarta: Gramedia Pustaka Utama

Barthos, B. (2012). Manajemen Kearsipan. Jakarta: Bumi Aksara

Dewi, I. C. (2011). Jakarta: Gramedia Pustaka Utama

Mirmani, A. (2011). Pengantar Kearsipan. Jakarta: Universitas Terbuka
Peraturan Bupati Tanah Datar Nomor 44 Tahun 2012 Tentang Pedoman Pengelolaan Arsip Dinamis Pemerintah Kabupaten Tanah Datar

Peraturan Pemerintah Republik Indonesia Nomor 28 Tahun 2012 Tentang Pelaksanaan Undang-undang Nomor 43 tahun 2009 tentang kearsipan (Lembaran Negara Republik Indonesia Tahun 2012 Nomor 53, Tambahan Lembaran Negara Nomor 5286).

Sugiyono. (2011). Metode penelitian Kuantitatif Kualitatif dan $R$ \& D.Bandung: Alfabeta

Sulistyo, B. (2003). Manajemen Arsip Dinamis. Jakarta: Gramedia Pustaka Utama. 